\author{
Praca poglądowa/Review paper
}

\title{
Wpływ greliny i obestatyny na właściwości fizjologiczne trzustki.
}

\section{The effect of ghrelin and obestatin on the physiological properties of the pancreas.}

\author{
Beata Szczepaniak ${ }^{1}$ \\ ${ }^{1}$ Zakład Fizyki Medycznej, Wielkopolskie Centrum Onkologii, Poznań, Polska
}

\section{Streszczenie}

W tej pracy opisane zostaną po krótce dwa hormony wpływające na fizjologiczne funkcjonowanie trzustki. Obestatyna i grelina to peptydy oddziałujące antagonistycznie wywierając wpływ na homeostazę glukozy $\mathrm{w}$ organizmie. Jak powszechnie wiadomo, zaburzenia metabolizmu glukozowego stoją u podstaw wielu schorzeń. Jednymi z najbardziej znanych są cukrzyca typu II oraz otyłość, stanowiące obecnie problem globalny. Ponad to nadmiar tkanki tłuszczowej może prowadzić do konsekwencji takich jak nowotworzenie w obrębie narządów układu pokarmowego[1]. Wysoce istotna wydaje się zatem rola obestatyny i greliny. Zdobyta w tym zakresie wiedza posłużyć może w poszukiwaniu rozwiązań terapeutycznych lub zapobiegawczych.

\begin{abstract}
This paper will briefly describe two hormones affecting the physiological functioning of the pancreas. Obestatin and ghrelin are peptides with antagonistic effects on glucose homeostasis in the body. As is well known, glucose metabolism disorders are at the root of many diseases. One of the best known are diabetes type II and obesity, which are currently a global problem. Moreover, the excess of adipose tissue may lead to consequences such as neoplasm within the gastrointestinal tract[1]. The role of obestatin and ghrelin therefore seems highly important. The knowledge gained in this area can be used to find therapeutic or preventive solutions.
\end{abstract}

Adres do korespondencji

Beata Szczepaniak

Pracownia Radiobiologii, Zakład Fizyki Medycznej

Wielkopolskie Centrum Onkologii, ul. Garbary 15, 61-866 Poznań, Polska

Telefon. +48 ?????????

e-mail: b.szczepaniak99@gmail.com 


\section{Cel}

Celem tej pracy jest stworzenie krótkiego opisu obestatyny i greliny w kontekście wpływu tych dwu peptydów na fizjologiczne funkcjonowanie trzustki.

Stowa kluczowe: grelina, obestatyna, trzustka, oddziaływanie, fizjologia

Keyword: ghrelin, obestatin, pancreas, interaction, physiology

\section{Trzustka}

Trzustka jest wyjątkowym narządem o dwojakiej funkcji. Składa się z pęcherzykowych komórek zewnątrzwydzielniczych pełniących funkcję trawienną. Wydzielają niezbędny w tym celu sok trawienny odprowadzany do dwunastnicy poprzez przewód wyprowadzający. Drugi typ komórek tworzy element trzustki endokrynnej. Stanowi blisko 2\% masy organu[2]. Komórki te biorą czynny udział w hormonalnej regulacji homeostazy glukozy w organizmie. Tworzą funkcjonalne jednostki hormonalne zwane Wyspami Langerhansa. W ich strukturze wyróżniamy 5 typów komórek: komórki alfa wydzielające glukagon ( $\alpha$ ), beta wydzielające insulinę $(\beta)$ - komórki, komórki delta $(\delta)$ wytwarzające somatostatynę, komórki zawierające polipeptyd trzustkowy (PP) i niedawno zidentyfikowano komórki epsilon ( $(\varepsilon)$ wytwarzające grelinę [2].

\section{Grelina}

Grelina jest 28-aminokwasowym hormonem o budowie peptydowej i strukturze zbliżonej do motyliny. Odpowiada głównie za stymulację uwalniania GH i regulację apetytu. Pierwotnie zidentyfikowano ją w żołądku szczura przez grupę japońskich badaczy w 1999 roku jako endogenny ligand dla receptora uwalniającego hormonu wzrostu (ang. growth hormone secretagoues-receptor [GHS-R]) [3].

Termin grelina pochodzi od indoeuropejskich słów „gre” i „relina”, które oznaczają kolejno „rosnąć” i „stymulować wydzielanie”, więc jak sama nazwa wskazuje, grelina stymuluje uwalnianie hormonu wzrostu, oddziałując w ten sposób pośrednio i bezpośrednio, synergistycznie z somatoliberyną, na przysadkę mózgową. Grelina wykazuje dodatni wpływ na czynnik transkrypcyjny Pit1. Jest on transkrybowany w przednim płacie przysadki mózgowej i prowadzi do ekspresji genu, który koduje w komórkach somatotropowych GH [4]. Grelina, jest hormonem, który jako jedyny obwodowo pobudza apetyt i pobieranie pokarmu. Działa przez stymulację komórek wydzielających neuropeptyd Y (ang. neuropeptide Y - NPY) oraz białko z rodziny Agouti (ang. Agoutirelated protein [AgRP]) w jądrze łukowatym podwzgórza oraz hamuje anne działania melanokortyny [5]. Grelina odpowiedzialna jest również za wzmaganie wydzielania kwasu solnego i uwalnianie gastryny. Reguluje aktywność motoryczną przewodu pokarmowego w tym ruchy perystaltycznie żołądka i jelit w okresach trawiennym i międzytrawiennym. Proces ten zachodzi pośrednio przy udziału włókien nerwu błędnego lub bezpośrednio poprzez swoiste receptory znajdujące się w żołądku [3].

Cząsteczka greliny swój początek bierze ze 117-aminokwasowego prekursora - preprogreliny. Ta z kolei kodowana jest przez gen GHRL. Udowodniono, iż gen ten występuje u wszystkich kręgowców. U ludzi znajduje się na chromosomie trzecim w rejonie 3p25-26. Składa się z 5 eksonów i 4 intronów [6]. Proteoliza preprogreliny daje początek 23-aminokwasowej sekwencji sygnałowej i 94-aminokwasowej progreliny. Później prohormon poddany zostaje przekształceniu, wskutek działania O-acetylotransferazy greliny (GOAT), która powoduje afiliację grupy oktanylowej do seryny w pozycji trzeciej łańcucha peptydowego. Następnie wskutek enzymatycznego cięcia poprzez konwertazę prohormonową PC1-3 w pozycji ARg28/ Ala29 powstaje dojrzała 28-aminokwasowa N-końcowa cząsteczka greliny[6].

Grelina występuje w dwóch formach molekularnych. Pierwsza to modyfikowana potranslacyjnie forma greliny, mająca przyłączoną grupę oktanylową do seryny w pozycji trzeciej łańcucha peptydowego. Acylowanie grupy hydroksylowej reszty seryny zachodzi przy użyciu GOAT i tak powstaje grelina acylowana (ang. 
Acolated Ghrelin - [AC]). Drugą izoformą jest desacylowana grelina (ang. Unacylated Ghrelin - [UAG]) i jak twierdzi Hosoda i wsp. jest ona nieaktywna biologicznie, mimo iż stanowi prawie 80\% greliny znajdującej się w osoczu[7]. Jest to stwierdzenie dość kontrowersyjne, ponieważ inni autorzy donoszą o działaniu deacylowanej greliny na przykład w obszarze limbicznym [8]. Inne badania dotyczące kardiotoksyczności, również potwierdzają o wpływie des-acyl greliny [9]. Kwestia ta zatem pozostaje dyskusyjna. Oprócz wcześniej wymienionych istnieje inny endogenny ligand dla receptora hormonu wzrostu o budowie niemal identycznej do greliny. Nazywany jest des-gln14greliną. Ta izoforma różni się od greliny delecją aminokwasu glutaminy w pozycji 14 łańcucha polipeptydowego i działa przez receptor GHS-R - tak samo jak grelina. Powstaje podczas alternatywnego splicingu genu greliny, a prekursorem hormonu jest 117-aminokwasowa prepro-desgln14grelina [7].

Receptory greliny są bardzo rozpowszechnione w organizmie. Występują w miejscach takich jak: podwzgórze, przysadka mózgowa i nadnercza, jajniki i jądra, macica, naczynia krwionośne i serce, tarczyca, płuca, wątroba, trzustka, nerki, tkanka tłuszczowa, mięśnie szkieletowe, skóra oraz węzły chłonne [10]. Tak obszerne występowanie skłoniło naukowców do prowadzenia licznych badań w celu pozyskania bardziej szczegółowych informacji o budowie i działaniu greliny.

Receptor GHS-R został odkryty w 1996 roku. Gen przez, który jest kodowany znajduje się na 3 chromosomie (3q26.2). Znane są obecnie dwa podtypy receptora greliny(1a i 1b), które powstają wskutek alternatywnego splicingu. Obie postaci są receptorami, które należą do rodziny receptorów sprzężonych z białkiem G. Pierwsza z form GHS-R1a to właściwy receptor greliny. Wykazuje plejotropową aktywność biologiczną, posiada 7 przezbłonowych domen i składa się z 366 aminokwasów. Ma on zdolność wiązania tylko z aktywną formą greliny, podczas gdy jak wskazuje wiele źródeł forma nieaktywna pozostaje wobec niego bierna. Ghs-r1b jest receptorem dość kontrowersyjnym, autorzy wciąż wspierają się o jego aktywność. Polińska i wsp donoszą o jego nieaktywności biologicznej, z kolei Chow i wsp. sugerują, że ghs-r1b zmniejsza ekspresję błon plazmatycznych receptorów greliny [6][11].

Grelina uwalniana jest głównie w dnie żołądka przez enteroendokrynne komórki okładzinowe X/A poza światło przewodu pokarmowego - do układu krążenia. Wydzielanie zachodzi zwykle w stanie ujemnego bilansu energetycznego organizmu, który zmienia na dodatni i utrzymuje poprzez pobudzenie apetytu i nasilenie pobierania pokarmu oraz oszczędzanie zużycia tkanki [12]. Sugeruje się równiė̇, że na wydzielanie greliny mogą mieć wpływ czynniki takie jak styl życia, stres czy częstotliwość ćwiczeń [13]. Badania wykazują, że stres, który stymuluje wydzielanie greliny u szczurów i ludzi powoduje następnie objadanie się, co potwierdza jej oreksygeniczne działanie. Grelinę zlokalizowana także w innych tkankach. W mniejszych ilościach została wykryta podwzgórzu, przysadce, układzie immunologicznym, trzustce, wątrobie, w jelicie cienkim, łożysku, nerkach, nadnerczach i sercu [14]. W obrazie ostatnich badań bardzo istotna wydaje się być również grelina wydzielana podczas głodu przez komórki $\varepsilon$ w endokrynnej części trzustki [15]. Ma to niebagatelne znaczenie kontekście interakcji z komórkami $\beta$ [16], na które wpływa grelina. Co ciekawe zaobserwowano, że w przeciwieństwie do osoby dorosłej trzustka może być głównym źródłem greliny w krwiobiegu podczas rozwoju macicznego [17]. Obecność greliny i jej receptora wykazano także w tkankach nowotworowych i pojawiają się dowody, że może ona mieć znaczenie w procesie nowotworzenia [1], a także posłużyć jako markerowe narzędzie diagnostyczno-prognostyczne [4][18].

Plejotropowa natura greliny [19] komplikuje pełne zrozumienie jej roli w etiologii dysfunkcji związanych z metabolizmem organizmu. Naukowcy wciąż jednak dociekają, czego skutkiem jest znakomita ilość donosów o zróżnicowanej efektywności zarówno o AG jak i UAG. Co ciekawe wyróżnia się rozbieżność już w zakresie wpływu tych dwu izoform. Na przykład badania nad oreksygenicznym działaniem greliny. Istnieje wiele donosów, które wskazują na znaczny wpływ acylowanej greliny na regulację apetytu i homeostazy energetycznej organizmu [20]. Podawana gryzoniom acylowana grelina powodowała nagły wzrost apetytu i ilości przyjmowanego pokarmu, a co za tym idzie wzrost masy ciała. Co ciekawe antagonistyczne efekty uzyskano wykorzystując w doświadczeniu DAG, gdzie po podaniu hormonu zmniejszała się ilości przyjmowanego pokarmu u myszy [21] i szczurów[22]. O ile wielu naukowców początkowo nie dawało 
szansy UAG i twierdziło, że acylowanie greliny jest kluczowe dla jej aktywności biologicznej, obecnie można spostrzec, iż istnieje spora grupa popierająca potencjał deacylowanej formy tego hormonu. W kilku badaniach podkreślono nawet zdolności UAG w utrzymywaniu żywotności oraz proliferacji komórek $\beta$ trzustki. Co więcej, UAG wydaje się nawet hamować wpływ na funkcje degeneracyjne trzustki [23][24] [25]. AG również wykazała porównywalne działania promując regenerację komórek $\beta$ i zwiększając ekspresję genu oraz wydzielanie insuliny u noworodków szczurzych leczonych streptozotocyną [26], co świadczy o jej niebywałych zdolnościach protekcyjnych. W podobnym doświadczeniu u szczurów traktowanych streptozotocyną zadziałał prozdrowotnie również UAG. Stwierdzono wówczas zwielokrotnienie powierzchni oraz liczebności wysepek trzustkowych [27]. Jest to bardzo budujące w perspektywie leczenia cukrzycy, gdzie upośledzone są te struktury funkcjonalne trzustki.

Obecnie powszechnie przyjmuje się, że działanie plejotropowe AG i UAG zależą od ich powinowactwa do wielu receptorów, które na tę chwilę są jeszcze nieznane. Autorzy spekulują, że niektóre mogą być nawet wspólne dla obu izoform [27]. Przeprowadzono eksperyment na komórkach INS-1E, o których wiadomo, że zarówno AG, jak i UAG stymulują uwalnianie insuliny. Doświadczenie obejmowało zastosowanie antagonisty GHS-R1 (ang. Growth Hormone Secretagogue Receptor type 1), a efekty sugerują, że działanieinsulinotropowe acylowanej greliny w komórkach $\beta$ może obejmować GHS-R1A, natomiast w przypadku UAG zaproponowano istnienie innego receptora pośredniczącego w jego działaniu [28]. Podobnie w przypadku doniesień z 2008 roku, które wykazały , że desacylowana grelina w stężeniu dziesięciokrotnie wyższym niż AG, znosi hamujący wpływ AG na wydzielanie insuliny z wysp trzustkowych myszy i szczurów, lecz prawdopodobnie wchodząc winterakcjezreceptorem innym niż GHS-R1A [29]. Innebadania również potwierdzajązałożenia poprzednich. Ponownie wykazano, że mimo iż UAG wykazuje tak samo jak acylowana grelina działanie anoreksogenne, a sygnalizacja zachodzi poprzez receptory inne od GHS-R1A [21]. Podkreślając istotną role greliny w regulacji wydzielania insuliny oraz poziomów glukozy w organizmie, przeprowadzono szereg badań mających na celu poznanie efektów tych oddziaływań oraz procesów towarzyszących tym interakcjom. Powstało wiele prac pozwalających zrozumieć mechanizmy działania tych dwóch hormonów. Badania opublikowane w American Journal of Physiology: Endocrinology and Metabolism przez Drott i wsp. wskazują, że endogenna grelina działa miejscowo zwężając naczynia krwionośne na wyspach trzustkowych u szczurów na czczo, efektem czego jest osłabienie odpowiedzi insulinowej [16]. To jedne z nielicznych badań donoszących o działaniu greliny na poziomie naczyniowym, lecz mają one istotne znaczenie dla zrozumienia mechanizmu inhibicji sekrecji insuliny pod wpływem greliny. Wyniki wskazujące, iż grelina jest istotnym obiektem badań w homeostazie glukozy uzyskał także kolejni naukowcy[30]. W tym eksperymencie grelina zmniejszała poziom insuliny indukowanej glukozą zarówno u ludzi, jak i gryzoni. Wykazano wówczas, że GHS-R ulega ekspresji w komórkach $\beta$ i że grelina hamuje sekrecje insuliny za pomocą szlaku, w którym pośredniczy Ca2+ [30]. Takie obserwacje u ludzi uzyskał również Broglio i wsp. Eksperyment ostrego leczenia greliną u zdrowych osób wywołał hiperglikemię oraz inhibicję sekrecji insuliny[31]. Podawanie antagonisty receptora greliny (GHRP-6) indukowało podobne efekty także u myszy [32]. Co ciekawe, działanie greliny podwyższające stężenia glukozy we krwi poprzez hamowanie wydzielania insuliny wydaje się być antagonizowane przez jednoczesne podawanie UAG [33]. Aby szczerzej przyjrzeć się jednak endogennej trzustkowej grelinie należy wyeliminować wpływ tego peptydu pochodzącego z żołądka. U szczurów po całkowitej resekcji żołądka, którym podawano dootrzewnowo GHRP-6 wykazano zwiększenie stężenia insuliny, lecz różnica nie była istotna w porównaniu ze szczurami zdrowymi. Można wnioskować zatem, że antagonista wpływa tylko na grelinę działającą lokalnie [32][16]. Również badania na perfundowanej trzustce szczura wykazały, ze antagonista GHS-R1 zwiększał stymulowane glukozą wydzielanie insuliny, a egzogenna grelina hamowała ten proces. [32]. Wyniki te sugerują, że ukierunkowane badań na komórki $\varepsilon$ - źródło endogennej greliny - może dać wiele odpowiedzi. W perspektywie niezbędne wydaje się być głębsze zbadanie szlaków sygnalizacyjnych tych komórek. Z pewnością możliwość regulacji greliny uwalnianej z komórek epsilon mogłaby przyczynić się do poprawy uwalniania insuliny i stabilizacji poziomu glukozy we krwi. Informacje takie mogą zagwarantować nowe możliwości w kontekście poszukiwania metod terapeutycznych zapobiegania i leczenia cukrzycy. 


\section{Obestatyna}

Obestatyna (ang. obestatin) jest 23 aminokwasowym peptydem, kodowanym przez ten sam gen co grelina. Jego nazwa pochodzi od dwóch łacińskich słów oberere i statin, oznaczających kolejno „pożerać” i „hamować”. Terminologia nawiązuje do wyników pierwszych doświadczeń mających na celu określenie właściwości fizjologicznych tego białka.

Badania na szczurach, którym podawano obestatynę wykazały jej udział między innymi w zmniejszeniu łaknienia, hamowaniu motoryki jelit i obniżaniu masy ciała [34]. Obecnie stwierdzenia te są często kwestionowane, bowiem na przestrzeni ostatnich lat badania dostarczyły sporo nowych informacji o wielofunkcyjności obestatyny w organizmie. Wyniki doświadczeń w zależności od wybranych gatunków zwierząt i metod badawczych niejednokrotnie były niespójne lub nawet sobie przeczyły. Badacze ciągle dociekają, jakie są ku temu powody projektując nowe eksperymenty. Z każdym kolejnym osiągnięciem naukowców poszerza się wiedza o obestatynie, co stwarza perspektywy wykorzystania jej właściwości na przykład w medycynie. Być może to właśnie obestatyna stanie się kluczowym czynnikiem w leczeniu chorób cywilizacyjnych związanych z otyłością, zaś wpływ duetu obestatyna-grelina na poziom insuliny, stwarza nowe perspektywy do walki z cukrzycą. Pojawiają się również założenia jakoby obestatyna wraz z greliną tworzyła osobny układ endokrynny. Ostatnie doniesienia sugerują także, związek zarówno obestatyny z rozwojem chorób nowotworowych w różnych narządach organizmu [35].

Odkryta przez Zhang i wsp. w 2005 roku obestatyna pierwotnie została wykryta w żołądku szczura, jako endogenny antagonista greliny. Badacze poprzez analizy przy użyciu technik bioinformatycznych zidentyfikowali, a następnie wyizolowali z żołądka szczura towarzyszący grelinie peptyd [34]. Mówi się także o występowaniu tych dwóch antagonistycznych białek w obrębie jednego pęcherzyka wydzielniczego [35].

Obestatyna powstaje w czasie polipeptydowej obróbki posttranslacyjnej cząsteczki preprogreliny. Preprogrelina zbudowana jest z 117 aminokwasów (aa). Stanowi prekursor zarówno, obestatyny jak i greliny. Pierwsze doświadczenia wskazywały, że preprogrelina koduje pojedynczy gen (GHRL). Składa się on z czterech eksonów, które zlokalizowane są na krótkim ramieniu chromosomu 3 [37]. Ponadto wykazane zostały również zróżnicowane warianty splicingowych prekursorów mRNA, które kodują preprogrelinę. W badaniach na ludzkiej preprogrelinie ustalono, że delecja eksonu $3 \mathrm{w}$ pre-mRNA preprogreliny spowoduje u powstałego na takiej matrycy prekursora kodowanie w pełni funkcjonalnej greliny i C-końcowego 16 aa peptydu $(\delta 3 \mathrm{D})$ o nieznanej funkcji, lecz nie obestatyny [37]. Natomiast syntezę prekursorów kodujących jedynie obestatynę warunkuje delecja w zakresie eksonów 1 i/lub $2 \mathrm{w}$ pre-mRNA preprogreliny [38]. W związku z tym, wnioskować można, iż to alternatywne składanie mRNA preprogreliny jest fundamentalnym procesem wpływającym na wykształcanie fizjologicznych cech obestatyny i greliny.

Obestatyna wiąże się z sierocym receptorem związanym z białkiem G GPR39 [34]. Receptor ten należy do grupy rodopsynopodobnych. Do tego grona należą także receptory np. hormonów wzrostu i motyliny [39]. Badania prowadzone nad procesem ekspresji genu kodującego GPR39 wskazały dwa warianty splicingowego mRNA owego receptora. Pierwszy z nich to GPR39-1a, który koduje kompletny w pełni funkcjonalny receptor, zbudowany z 423 aa i posiadający siedem domen transbłonowych. Według badaczy występuje głównie w układzie pokarmowym. Drugą z form jest składający się z 284 aa receptor GPR39-1b, będący bardziej rozpowszechnionym w organizmie. Występuje nie tylko w układzie pokarmowym, ale także w tkance tłuszczowej, komórkach mięśnia sercowego, ośrodkowym układzie nerwowym oraz śledzionie [37].

Obestatyna syntetyzowana jest głównie w immunoreaktywnych komórkach typu a błony śluzowej dna żołądka. Należą one do populacji neuroendokrynnych komórek okładzinowych zawierających obestatynę wraz z preprogreliną i pankreatyną oraz częściowo z greliną (60\%). Peptyd z żołądka trafia do krwiobiegu i przejawia tam działania o charakterze endokrynnym. Nie posiada mimo to - w przeciwieństwie do greliny - umiejętności przekraczania bariery krew-mózg, czego dowiodły badania prowadzone przez Pan i wsp. [40]. Ci sami autorzy wskazują także, że obestatyna znajdująca się w osoczu krwi szybko degraduje. W badaniach przeprowadzonych na szczurach wykazano, że już w pierwszym dniu życia obecne są w błonie śluzowej 
żołądka komórki, które zawierają obestatynę. Ilość tych komórek wzrasta, aż do 6 tygodnia życia, wówczas osiąga swoje maksimum. Komórki immunoreaktywne choć w mniejszej ilości w stosunku do obestatyny, zostały wykryte u gryzoni także w błonie śluzowej jelita[36][37][41] wysepkach trzustkowych, nabłonku gruczołu mlekowego[36], wątrobie, płucach [37], żołądku i dwunastnicy [36][41]. Obecność obestatyny zbadano także w ludzkich tkankach [35]. Ekspresję białka zaobserwowano z przysadce, płucach, trzustce i odcinku żołądkowo jelitowym [35]. W tych miejscach obestatyna współwystępowała z greliną. Ponad obestatynę wykryto również w tkankach nowotworowych między innymi tarczycy, przytarczyc, przewodu pokarmowego czy trzustki, gdzie również współlokalizowana była z greliną[41]. Reasumując stwierdzić można, iż obestatyna wytwarzana jest przez komórki, które jednocześnie wyrażają grelinę i występuje tkankach normalnych zarówno za życia płodowego, jak i dorosłego. Ponad to dodatkowo występuje w stanach nowotworowych lecz jej obecność jest mniejsza wskutek potranslacyjnej modulacji.[37][39][41]

Od początku identyfikacji obestatyny zakłada się, że ma ona działania anoreksygenne działając jako antagonista greliny. Sądzono, że zmniejszała przyjmowanie pokarmu i przyrost masy ciała, hamowała opróżnianie żołądka oraz perystaltykę jelitową. Te efekty potwierdziły badania na szczurach, którym podawano obestatynę [34]. Jednak w miarę postępu badań, pojawiło się wiele spekulacji dotyczących jej funkcji. Obecnie sugeruję się, że obestatyna nie jest endogennym antagonistą greliny, a jej funkcje w organizmie mogą być znacznie szersze niż początkowo zakładano. Okazało się bowiem, że obestatyna podobnie jak grelina może posiadać zdolności promujące przeżycie i proliferację komórek , a nawet właściwości przeciwzapalne [42]. Wykazano, że obestatyna sprzyja przeżyciu komórek $\beta$ i ludzkich wysp trzustkowych in vitro, a ponad to aktywuje szlaki sygnałowe i indukcje ekspresji genów, które regulują wzrost komórek $\beta$, różnicowanie, biosyntezę insuliny i metabolizm glukozy[43]. Są to doniesienia istotne w kontekście walki z cukrzycą typu pierwszego, gdzie apoptoza komórek $\beta$ powodowana przez cytokiny, to dobrze znany obraz [44]. Co więcej udowodniono również potencjał właściwości antyproliferacyjnych in vitro $\mathrm{w}$ nowotworowych liniach komórkowych TT i BON-1, gdzie obestatyna wywoływała działanie antyproliferacyjne w dawkach farmakologicznych, odwrotnie niż w przypadku greliny [35]. Jest to ciekawa obserwacja w perspektywie leczenia nowotworów trzustki. Obestatyna pozostaje nadal kontrowersyjna w kwestii jej wpływu na oś hormonalną trzustki. I choć badania te są dość istotne dla poznania regulacyjnej roli obestatyny w metabolizmie glukozowym organizmu, w odniesieniu do wydzielania insuliny rola obestatyny nadal pozostaje kwestią sporów. Wykazano zarówno działanie hamujące, jak i stymulujące tego peptydu[45]. Badania na szczurach in vivo oraz inkubowanych szczurzych wysepkach in vitro wykazały działanie obestatyny jako silnego inhibitora wydzielania insuliny [46]. Inni autorzy otrzymali wyniki zupełnie antagonistyczne. Obestatyna spowodowała bowiem uwalnianie insuliny w odpowiedzi na glukozę, $\mathrm{w}$ warunkach in vitro zarówno w liniach komórek $\beta$ jak i ludzkich wysepkach trzustkowych [43]. Ci sami autorzy uzyskali równoznaczny efekt in vivo na wysepkach trzustkowych myszy karmionych dietą o niskiej i wysokiej zawartości tłuszczu [47]. Ponad to uzyskano również podwójny, zależny od dawki wpływ obestatyny w perfundowanej trzustce szczura w obecności glukozy $(9 \mathrm{mM})$ obestatyna stymulowała wydzielanie insuliny przy niskich jej stężeniach (3,14 $\mathrm{nM}$ i $1 \mathrm{nM})$, ale hamowała wydzielanie insuliny przy wyższym (10 nM) [48]. Z kolei w doświadczeniach na myszach, którym dootrzewnowo podawana była obestatyna ukazały jej wpływ na regulację metabolizmu poprzez zmiany apetytu, lecz nie wskazano bezpośredniego działania na wydzielanie insuliny ani na homeostazę glukozy w organizmie [49[]. Przeciwnie zareagowały jednak szczury, którym dożylnie podawano obestatynę. Wówczas nie wywołano żadnego wpływu na stężenie glukozy i insuliny, zarówno ogólnoustrojowe, jak i wrotne, w porównaniu do grup kontrolnych [50]. Wnioskować można zatem, że odpowiedź na obestatynę jest w jakimś stopniu zależna gatunkowo, choć rozbieżność wyników w tak wielu płaszczyznach sugeruję także rolę warunków eksperymentalnych. Pewne jest jednak, że jako czynnik insulinotropowy potencjalne działanie przeciwcukrzycowe obestatyny jest warte uwagi. Szereg odkryć o stymulującym na insulinę działaniu obestatyny oraz innymi korzystnymi jej skutkami w kontekście komórek $\beta$ sprawia, że obestatyna staje się atrakcyjnym kandydatem w leczeniu cukrzycy typu 2. 


\section{Podsumowanie}

Podsumowując dotychczasowe rozważania można stwierdzić, iż grelina i obestatyna są bardzo istotnymi graczami w regulowaniu funkcji fizjologicznych trzustki. Dzięki ich zdolnościom do wpływania na stężenie insuliny, a co za tym idzie również na gospodarkę węglowodanową organizmu istnieje duże prawdopodobieństwo zastosowania tego duetu w terapii przeciw otyłości i cukrzycy, a nawet niektórych chorób nowotworowych.

\section{Piśmiennictwo / References}

[1] Calle EE, Rodriguez C, Walker-Thurmond K, Thun MJ. Overweight, obesity, and mortality from cancer in a prospectively studied cohort of U.S. adults. N Engl J Med. 2003 Apr 24;348(17):1625-38.

[2] Shahid Z, Singh G. Physiology, Islets of Langerhans. [Updated 2019 May 15]. In: StatPearls [Internet]. Treasure Island (FL): StatPearls Publishing, 2020 Jan-. Available from: https://www.ncbi.nlm.nih.gov/ books/NBK542302/

[3] Kojima M, Hosoda H, Date Y, Nakazato M, Matsuo H, Kangawa K. Ghrelin is growth-hormone-releasing acylated peptide from stomach, Nature. 1999; 402(6762): 656-60

[4] Nikolopoulos D, Theocharis S, Kouraklis G. Ghrelin: a potential therapeutic target for cancer. Regul Pept. 2010 Aug 9;163(1-3):7-17. doi: 10.1016/j.regpep.2010.03.011

[5] Castaneda TR, Tong J, Datta R, Culler M, Tschöp MH. Ghrelin In the regulation of body weight and metabolism. Frontiers in Neuroendocrinol. 2010; 31: 44-60

[6] Polińska B, Matowicka-Karna J, Kemona H. The role of ghrelin in the organism. Postepy Hig Med Dosw (online). 2011; 65: 1-7

[7] Hosoda H, Kojima M, Matsuo H, Kangawa K. Purification and characterization of ratdes Gln14-ghrelin, a second endogenous ligand for the growth hormone secretaagogue receptor. The Journal of Biological Chemistry. 2000; 275(29): 21995-22000

[8] Portelli J, Coppens J, Demuyser T, Smolders I. Neuropeptides. Des-acyl ghrelin attenuates pilocarpineinduced limbic seizures via the ghrelin receptor and not the orexin pathway. 2015 Jun;51:1-7. doi: 10.1016/j.npep.2015.04.004. Epub 2015 May 8.

[9] Nonaka M, Kurebayashi N, Murayama T, Sugihara M, Terawaki K, Shiraishi S i in. Therapeutic potential of ghrelin and des-acyl ghrelin against chemotherapy-induced cardiotoxicity. Endocr J. 2017; 64(Suppl.):S35-S39. doi: 10.1507/endocrj.64.S35.

[10] Jaszczyńska-Nowinka K, Markowska A. Rola ghreliny i obestatyny w procesach metabolicznych i nowotworowych u ludzi. Curr. Gynecol. Oncol. 2010; 8 (2), p. 131-138

[11] Chow KBS, Sun J, Man Chu K, Tai Cheung W, Cheng CHK., Wise H. The truncated ghrelin receptor polypeptide (GHS-R1b) is localized in the endoplasmic reticulum where it forms heterodimers with ghrelin receptors (GHS-R1a) to attenuate their cell surface expression Molecular and Cellular Endocrinology. 2012; 348 (1), pp. 247-254. doi.org/10.1016/j.mce.2011.08.034

[12] Cummings D.E. Ghrelin and the short-time- and long-term regulation of appetite and body weight. Physiology \& Behavior. 2006; 89(1): 71-84

[13] Adams CE, Greenway FL, Brantley PJ. Lifestyle factors and ghrelin: critical review and implications for weight loss maintenance. Obesity Management. 2010; 10.1111

[14] Michalski B., Krzemińska-Pakuła M., Kasprzak J.D. The way to the heart is through the stomach - the role of ghrelin in pathogenesis of cardiovascular disease, Kardiologia Polska. 2008; 66(5): 564-568

[15] Drott CJ, Franzén P, Carlsson PO. Ghrelin in rat pancreatic islets decreases islet blood flow. Am J Physiol Endocrinol Metab. 2019 Jul 1;317(1):139-146. doi: 10.1152/ajpendo.00004.2019.

[16] Sakata N, Yoshimatsu G, Kodama S. Development and Characteristics of Pancreatic Epsilon Cells. Int J Mol Sci. 2019;20(8):1867. Published 2019 Apr 16. doi:10.3390/ijms20081867

[17] Wierup N, Sundler C. Circulating ghrelin levels in human fetuses. Eur J Endocrinol. 2004; 150 (3): 405

[18] Zhang J, Xie T. Ghrelin inhibits cisplatin-induced MDA-MB-231 breast cancer cell apoptosis via PI3K/ Akt/mTOR signaling. Exp Ther Med. 2020 Mar;19(3):1633-1640. doi: 10.3892/etm.2019.8398.

[19] Poher AL, Tschöp MH, Müller TD. Ghrelin regulation of glucose metabolism. Peptides. 2018 Feb;100:236- 
242. doi: 10.1016/j.peptides.2017.12.015.

[20] Müller TD, Nogueiras R, Andermann ML, Andrews ZB, Anker SD, Argente J i in. Ghrelin. Mol Metab. 2015 Mar 21;4(6):437-6o. doi: 10.1016/j.molmet.2015.03.005. eCollection 2015 Jun.

[21] Perboni S, Inui A. Appetite and gastrointestinal motility: Role of ghrelin-family peptides. Clin. Nutr. 2010; 29(2): 227-234

[22] Chen CY, Inui A, Asakawa A, Fujino K, Kato I, Chen CC i in. Des-acyl ghrelin acts by CRF type 2 receptors to disrupt fasted stomach motility in conscious rats. Gastroenterology. 2005 Jul;129(1):8-25

[23] Granata R, Settanni F, Julien M, Nano R, Togliatto G, Trombetta A i in. Des-acyl ghrelin fragments and analogues promote survival of pancreatic $\beta$-cells and human pancreatic islets and prevent diabetes in streptozotocin-treated rats. J. Med. Chem. 2012; $55: 2585-2596$.

[24] Granata R., Settanni F., Trovato L., Destefanis S., Gallo D, Martinetti M i in. Unacylated as well as acylated ghrelin promotes cell survival and inhibit apoptosis in HIT-T15 pancreatic beta-cells. J Endocrinol Invest. 2006 Oct;29(9):RC19-22.

[25] Granata R., Settanni F., Biancone L., Trovato L., Nano R., Bertuzzi F i in. Acylated and unacylated ghrelin promote proliferation and inhibit apoptosis of pancreatic beta-cells and human islets: involvement of 3',5'-cyclic adenosine monophosphate/protein kinase A, extracellular signal-regulated kinase 1/2, and phosphatidyl inositol 3-Kinase/Akt signaling. Endocrinology. 2007 Feb;148(2):512-29. Epub 2006 Oct 26.

[26] Irako T, Akamizu T, Hosoda H, Iwakura H, Ariyasu H, Tojo K i in. Ghrelin prevents development of diabetes at adult age in streptozotocin-treated newborn rats. Diabetologia. 2006; 491264-1273. doi:10.1007/so0125-006-0226-3.

[27] Granata R, Baragli A, Settanni F, Scarlatti F, Ghigo E. Unraveling the role of the ghrelin gene peptides in the endocrine pancreas. J Mol Endocrinol. 2010 Sep;45(3):107-18. doi: 10.1677/JME-10-0019. Epub 2010 Jul 1.

[28] Gauna C, Delhanty PJ, van Aken MO, Janssen JA, Themmen AP, Hofland LJ i in. Unacylated ghrelin is active on the INS-1E rat insulinoma cell line independently of the growth hormone secretagogue receptor type 1a and the corticotropin releasing factor 2 receptor. Molecular and Cellular Endocrinology. 2006; 251103-111. doi:10.1016/j.mce.2006.03.040.

[29] Qader SS, Håkanson R, Rehfeld JF, Lundquist I, Salehi A. Proghrelin-derived peptides influence the secretion of insulin, glucagon, pancreatic polypeptide and somatostatin: A study on isolated islets from mouse and rat pancreas. Regulatory Peptides. 2008; 146:230-237

[30] Alamri BN, Shin K, Chappe V, Anini Y. The role of ghrelin in the regulation of glucose homeostasis. Horm Mol Biol Clin Investig. 2016 Apr 1;26(1):3-11. doi: 10.1515/hmbci-2016-0018.

[31] Broglio F, Arvat E, Benso A i in. Grelin, the stomach's natural secretory of growth hormone, induces hyperglycemia and reduces insulin secretion in humans. J Clin Endocrinol Metab. 2001; 86 (10): 5083 $-5083,5086$

[32] Napolitano T, Silvano S, Vieira A, Balaji S, Garrido-Utrilla A, Friano ME i in. Role of ghrelin in pancreatic development and function. Diabetes, Obes. Metab. 2018; 20 (Supl. 2): 3-10. doi: 10.1111 / dom.13385.

[33] Broglio F, Gottero C, Prodam F, Gauna C, Muccioli G, Papotti M i in. Non-acylated ghrelin counteracts the metabolic but not the neuroendocrine response to acylated ghrelin in humans. J Clin Endocrinol Metab. 2004 Jun;89(6):3062-5.

[34] Zhang JV, Ren PG, Avsian-Kretchmer O, Luo CW, Rauch R, Klein C i in. Obestatin, a peptide encoded by the ghrelin gene, opposes ghrelin's effects on food intake. Science. 2005 Nov 11;310(5750):996-999

[35] Volante M, Roses R, Ceppi P, Rapa I, Cassoni P, Wiedenmann B i in. Obestatin in human neuroendocrine tissues and tumours: expression and effect on tumour growth. J Pathol. 2009 Aug;218(4):458-66. doi: 10.1002/path.2551.

[36] Gronberg M, Tsolakis AV, Magnusson L, Janson ET, Saras J. (2008) Distribution of obestatin and ghrelin in human tissues: immunoreactive cells in the gastrointestinal tract, pancreas, and mammary glands. Journal of Histochemistry and Cytochemistry 56(9): 793-801

[37] Słupecka M, Woliński, Herman AP, Ochniewicz P, Kornacka MK. Biological role of obestatin in physiology and pathophysiology, Medycyna Wieku Rozwojowego. 2012; 16(1):47-52

[38] Seim I, Collet C, Herington AC. Revised genomic structure of the human ghrelin gene and identification 
of novel exons, alternative splice variants and natural antisense transcripts. BMC Genomics. 2007; 8: 298

[39] Egerod KL, Holst B, Petersen PS, et al. GPR39 splice variants versus antisense gene LYPD1: expression and regulation in gastrointestinal tract, endocrine pancreas, liver, and white adipose tissue. Mol. Endocrinol., 2007, 21, 1685-1698

[40] Pan W, Tu H, Kastin AJ. Differential BBB interactions of three ingestive peptides: obestatin, ghrelin, and adiponectin. Peptides. 2006; 27(4):911-916

[41] Zhao CM, Furnes MW, Stenström B, Kulseng B, Chen D. Characterization of obestatin- and ghrelinproducing cells in the gastrointestinal tract and pancreas of rats: an immunohistochemical and electronmicroscopic study. Cell Tissue Res. 2008 Mar;331(3):575-87. Epub 2007 Dec 11.

[42] Ceranowicz P, Warzecha Z, Dembinski A, Cieszkowski J, Dembinski M, Sendur Ri in. Pretreatment with obestatin inhibits the development of cerulein-induced pancreatitis. J. Physiol. Pharmacol. 2009; 60, 95- 101.

[43] Granata R, Settanni F, Gallo D, Trovato L, Biancone L, Cantaluppi V i in. Obestatin promotes survival of pancreatic beta-cells and human islets and induces expression of genes involved in the regulation of beta-cell mass and function. Diabetes. 2008 Apr;57(4):967-79. Epub 2007 Dec 27.

[44] Donath MY, Halban PA. Decreased beta-cell mass in diabetes: significance, mechanisms and therapeutic implications. Diabetologia. 2004 Mar;47(3):581-589. doi: 10.1007/s00125-004-1336-4. Epub 2004 Feb 7.

[45] Gesmundo I, Gallo D, Favaro E, Ghigo E, Granata R. Obestatin: a new metabolic player in the pancreas and white adipose tissue. IUBMB Life. 2013 Dec;65(12):976-82. doi: 10.1002/iub.1226. Epub 2013 Nov 12.

[46] Ren AJ, Guo ZF, Wang YK, Wang LG, Wang WZ, Lin L i in. Inhibitory effect of obestatin on glucoseinduced insulin secretion in rats. Biochem Biophys Res Commun. 2008 May 9;369(3):969-72. doi: 10.1016/j.bbrc.2008.02.146. Epub 2008 Mar 7.

[47] Granata R, Gallo D, Luque RM, Baragli A, Scarlatti F, Grande C i in. Obestatin regulates adipocyte function and protects against diet-induced insulin resistance and inflammation. FASEB J. 2012 Aug;26(8):3393-411. doi: 10.1096/fj.11-201343. Epub 2012 May 17.

[48] Egido EM, Hernández R, Marco J, Silvestre RA. Effect of obestatin on insulin, glucagon and somatostatin secretion in the perfused rat pancreas. Regul Pept. 2009 Jan 8;152(1-3):61-6. doi: 10.1016/j. regpep.2008.08.003. Epub 2008 Aug 19

[49] Green BD, Irwin N, Flatt PR. Direct and indirect effects of obestatin peptides on food intake and the regulation of glucose homeostasis and insulin secretion in mice. Peptides. 2007 May;28(5):981-7. Epub 2007 Feb 12

[50] Kiewiet RM, Gauna C, van Aken MO, van de Zande B, van der Lely AJ. Bolus administration of obestatin does not change glucose and insulin levels neither in the systemic nor in the portal circulation of the rat. Peptides. 2008 Dec;29(12):2144-9. doi: 10.1016/j.peptides.2008.09.011. Epub 2008 Sep 26. 